\title{
LOCAL CURRENCY MODEL: TO BOOST ECONOMIC ACTIVITIES OF INDIGENOUS COMMUNITY IN MALAYSIA
}

\author{
Jarita Duasa \\ Department of Economics, International Islamic University Malaysia; jarita@iium.edu.my \\ Mohamed Asmy Mohd Thas Thaker \\ Department of Economics, International Islamic University Malaysia; asmy@iium.edu.my \\ Maya Puspa Rahman \\ Department of Economics, International Islamic University Malaysia; mayapuspa@iiium.edu.my
}

\begin{abstract}
The study proposes the local currency model to the Malaysian Indigenous community (Orang Asli) since they are among the nation's hardcore poor. It attempts to measure the probability and level of acceptance in the community if the complementary currency system were to be introduced for their economic activities. Using primary data collected from the survey among Orang Asli in Peninsular Malaysia, the study analyzes the data using Logit model and Technology Acceptance Model (TAM). Results from logistic regression imply that the probability to opt for proposed local currency as an alternative currency is high if it is using agricultural products and backed by national currency. The probability is also high among higher income respondents but low for those with big family size and those who prefer to use Ringgit Malaysia (RM). Using TAM, it is found that 'perceived usefulness' and 'perceived ease of use' have positive effect on 'attitude' to use the proposed local currency. Similar results are found between 'perceived usefulness' and 'behavioral intention' to use the proposed currency. Thus, through positive attitude, the respondent's perceptions on the usefulness and ease of use positively affect the behavioral intention of using the new system. The findings could assist the policymakers in implementing local currency model to Orang Asli community to boost their economic activities and pull them out from the circle of hardcore poverty among nations.
\end{abstract}

Keywords: Local currency, Malaysia, Logit model, Technology Acceptance Model

\section{Introduction}

The Orang Asli are the indigenous people of Peninsular Malaysia. They reside mostly in Peninsular Malaysia, with an estimated total population of 178,197 which represents approximately 0.6 per cent of the total population in Malaysia (JAKOA, 2016). They are classified into three main ethnolinguistic groups called the Senoi, Proto-Malays and Negritos. In 2011, the total number of Orang Asli population was 178,197. The Orang Asli are among the most marginalized and impoverished of Malaysia's inhabitants (Nicholas, 2002). Despite making up of only 0.6 per cent of the total national population, the Orang Asli accounts for about 20 per cent of the nation's hardcore poor (Nicholas, 2011).

Local currency or complementary currency (CC)can be defined as "something else than a legal tender (ie. national money) that can be used as a medium of exchange, with the purpose to link unmeet needs with otherwise unused resources" (Lieter and Hallsmith, 2006). Normally, the complementary currencies are issued by a group of local activists or an organization and one of the characteristics is their limited area of circulation. By types, they could be fully backed by the national currency, backed by guarantees from members of the exchange system, backed by goods or backed by services. In 2007, there were about 2,600 complementary currencies in the world, of which 55\% were in Europe, $36 \%$ in Japan, $5 \%$ in the US and Canada, 3\% in Australia and New Zealand, and only $1 \%$ in the rest of the world. Studies on the use of these currencies in many countries such as Brazil, Argentina, Iran, Japan and others have shown the successfulness of the model to improve local economic development and resolving social issues such as increase employment opportunities, empowering the poor people, ensuring social engagement and in some cases favoring gender balance.

The complementary or local currencies movement has been growing rapidly since the 1990s, and includes a diverse range of systems in developed and developing countries (DeMeulenaere, 2007). 


\section{The Turkish Online Journal of Design, Art and Communication - TOJDAC ISSN: 2146-5193, September 2018 Special Edition, p.xx-xx}

Since the early 1980s a range of different complementary currencies have emerged, many of them from civil society (see Kent, 2005; North, 2010; Schroeder, Miyazaki \& Fare, 2011). Such currency systems have been researched from a variety of different perspectives, such as policy tools (Williams et al., 2001) and social movements (North, 2006). Many of these have explicit links to sustainability objectives and the green movement (Helleiner, 2000; Longhurst \& Seyfang, 2011; North, 2010; Seyfang, 2009; Douthwaite, 1999).

Given the facts that Orang Asli community are poor but producing agricultural products (such as corn or rice) in abundance and they also in needs of other goods and services such as basic education, transportation etc., the proposed model of local currency seems very suitable to be developed within this community to improve the community's standard of living. Thus, the present study attempts to proposed local currency models to Orang Asli community in Malaysia and to assess the probability that the members of community will opt for the proposed models of CC and the acceptance level of the community of this model.

\section{Data and methodology}

A survey is conducted in the present study for data collection. In order to determine the appropriate sample size, this research applies the widely used formula by Yamane (1967). From the calculation, using the population size of 7,321 (the hardcore poverty number in 2011 based on JAKOA report) and 5 per cent level of precision or sampling error, it is suggested that the minimum sample size is 379 . However, the present study able to collect 1,082 data from almost all states of Peninsula Malaysia.

The present study adopts two methods of analysis. First, the logistic model, which is used to analyze the probability that respondents are willing to opt for the complementary currency as an alternative currency. This is a nonlinear regression model specifically designed for binary dependent variables. Unlike linear probability model, this model adopts a nonlinear formulation that forces the predicted values to be between 0 and 1 by using cumulative probability distribution function (c.d.f.) The population logit model of the binary dependent variable $\mathrm{Y}$ with multiple regressors could be expressed as:

$$
\begin{aligned}
& \operatorname{Pr}\left(Y=1 \mid X_{1}, X_{2} \ldots \ldots \ldots\right)=F\left(\beta_{0}+\beta_{1} X_{1}+\beta_{2} X_{2}+\ldots \ldots+\beta_{k} X_{k}\right) \\
& =\frac{1}{1+e^{-\left(\beta_{0}+\beta_{1} X_{1}+\beta_{2} X_{2}+\ldots .+\beta_{k} X_{k}\right)}}
\end{aligned}
$$

For the purpose of this study, the dependent or the outcome variable of interest was constructed as dichotomous indicator based on the response to survey question: "The complementary currency can be an alternative for the national currency". Respondents who answered 'Agree/strongly agree' is coded as 1 and those who answer 'Disagree/strongly disagree' is coded as 0 . The predictor variables consist of dummy variables, categorical variables and continuous variables.

Second, Technology Acceptance Model (TAM) is also adopted to further strengthen the analysis. TAM is a theoretical model explains and predicts user behavior of information technology and it is considered an influential extension of theory of reasoned action (TRA). TAM provides a basis with which one traces how external variables influence belief, attitude, and intention to use. Two cognitive beliefs are posited by TAM: 'perceived usefulness'(PU) and 'perceived ease of use' (PEOU). According to TAM, one's actual use of a technology system is influenced directly or indirectly by the user's behavioral intentions (BI), attitude (ATT), perceived usefulness of the system, and perceived ease of the system. TAM also proposes that external factors affect intention and actual use through mediated effects on perceived usefulness and perceived ease of use. Fig. 1 depicts the TAM (Davis, 1989). 


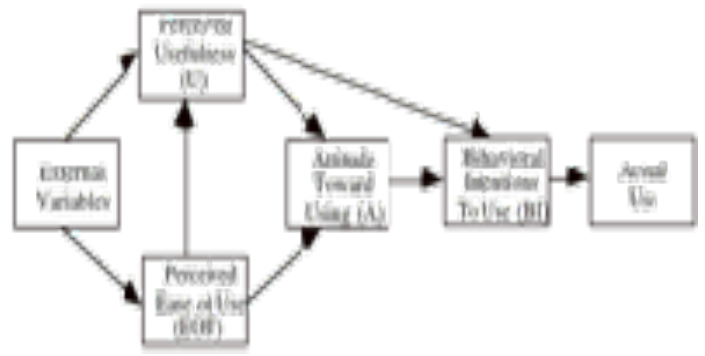

Fig. 1: Technology Acceptance Model (TAM)

\section{Results and discussion}

Logistic regression results

From Table 1, the regression results show that the significant predictors in the model are 'Family size', 'Dummy that agricultural product is suitable as CC', 'Dummy that unused tool is suitable as CC', 'Dummy that CC should be backed by RM', 'Dummy that CC should be able to defer transaction', 'Dummy that CC is chosen if it benefits me and family members', 'Dummy that RM is preferable to be used among local community' and 'Income level more than RM2000 per month'. The independent variables of the categorical variables such as income level, education level, marital status and job status are interpreted in such a way that the coefficients or betas are the difference between the focus category as compared to

Table 1: Logistic regression results

\begin{tabular}{|c|c|c|}
\hline \multirow{3}{*}{ Independent variables } & \multirow{2}{*}{\multicolumn{2}{|c|}{$\begin{array}{c}\text { Binary logistic } \\
\text { Dependent variable: } C C \text { CAN BE AN } \\
\text { ALTERNATIVE CURRENCY TO RM } \\
(\text { Agree }=1, \text { Disagree }=0)\end{array}$}} \\
\hline & & \\
\hline & $B$ & $\operatorname{Exp}(B)$ \\
\hline Constant & $\begin{array}{c}9.11 \\
(40194)\end{array}$ & 9023.9 \\
\hline Dummy_Gender & $\begin{array}{c}0.21 \\
(0.32)\end{array}$ & 1.23 \\
\hline Age & $\begin{array}{c}0.01 \\
(0.01)\end{array}$ & 1.01 \\
\hline Family size & $\begin{array}{c}-0.13^{* *} \\
(0.05)\end{array}$ & 0.88 \\
\hline Dummy_agr.product suitable & $\begin{array}{c}2.65^{* * * *} \\
(0.29)\end{array}$ & 14.19 \\
\hline Dummy_unused.tools suitable & $\begin{array}{c}1.07 * * * \\
(0.27)\end{array}$ & 2.94 \\
\hline Dummy_CC shld backed by RM & $\begin{array}{c}1.74 * * * \\
(0.49)\end{array}$ & 5.69 \\
\hline Dummy_CC shld have stable value & $\begin{array}{l}-1.18 \\
(0.73)\end{array}$ & 0.31 \\
\hline Dummy_CC shld be acceptable by community & $\begin{array}{l}-1.09 \\
(0.69)\end{array}$ & 0.34 \\
\hline Dummy_CC shld be convenience & $\begin{array}{c}0.66 \\
(0.75)\end{array}$ & 1.94 \\
\hline
\end{tabular}


The Turkish Online Journal of Design, Art and Communication - TOJDAC ISSN: 2146-5193, September 2018 Special Edition, p.xx-xx

\begin{tabular}{|c|c|c|}
\hline Dummy_CC shld be able to defer transaction & $\begin{array}{l}1.33 * * \\
(0.64)\end{array}$ & 3.79 \\
\hline Dummy_CC shld be durable & $\begin{array}{c}0.68 \\
(0.68)\end{array}$ & 1.97 \\
\hline Dummy_will use CC if benefit me and family & $\begin{array}{c}1.42^{* * * *} \\
(0.49)\end{array}$ & 4.13 \\
\hline Dummy_heard about CC in Malaysia & $\begin{array}{l}-0.39 \\
(0.29)\end{array}$ & 0.68 \\
\hline Dummy_heard about CC in other countries & $\begin{array}{c}0.59 \\
(0.37)\end{array}$ & 1.80 \\
\hline Dummy_prefer to use RM & $\begin{array}{c}-2.63^{* *} \\
(1.18)\end{array}$ & 0.72 \\
\hline Dummy_ever use RM in daily activities & $\begin{array}{l}2.06 \\
(3.63)\end{array}$ & 7.88 \\
\hline \multicolumn{3}{|l|}{ Education_none } \\
\hline Education_primary & $\begin{array}{l}-14.86 \\
(40194)\end{array}$ & 0.00 \\
\hline Education_secondary & $\begin{array}{l}-14.16 \\
(40194)\end{array}$ & 0.00 \\
\hline Education_diploma/pre-U & $\begin{array}{l}-14.81 \\
(40194)\end{array}$ & 0.00 \\
\hline Education_degree & $\begin{array}{l}-15.30 \\
(40194)\end{array}$ & 0.00 \\
\hline \multicolumn{3}{|l|}{ Marital status_single } \\
\hline Maritakstatus_married & $\begin{array}{l}-0.61 \\
(1.18)\end{array}$ & 0.54 \\
\hline Marital status_divorce & $\begin{array}{l}-0.77 \\
(1.13)\end{array}$ & 0.46 \\
\hline \multicolumn{3}{|l|}{ Income_<RM500 } \\
\hline Income_up to RM1000 & $\begin{array}{c}1.83 \\
(1.45)\end{array}$ & 6.26 \\
\hline Income_up to RM1500 & $\begin{array}{c}1.31 \\
(1.45)\end{array}$ & 3.72 \\
\hline Income_up to RM2000 & $\begin{array}{c}0.94 \\
(1.48)\end{array}$ & 2.56 \\
\hline Income_>RM2000 & $\begin{array}{c}5.86^{* * *} \\
(2.18)\end{array}$ & 349.02 \\
\hline \multicolumn{3}{|l|}{ Job status_public sector } \\
\hline Job status_private sector & $\begin{array}{c}0.26 \\
(1.00)\end{array}$ & 1.29 \\
\hline Job status_self-employed & $\begin{array}{c}0.66 \\
(0.89)\end{array}$ & 1.94 \\
\hline Jobstatus_home maker & $\begin{array}{l}0.85 \\
(0.85)\end{array}$ & 2.33 \\
\hline
\end{tabular}

Submit Date: 11.12.2017, Acceptance Date: 25.03.2018, DOI NO: 10.7456/1080SSE

Research Article - This article was checked by Turnitin

Copyright $@$ C The Turkish Online Journal of Design, Art and Communication 
The Turkish Online Journal of Design, Art and Communication - TOJDAC ISSN: 2146-5193, September 2018 Special Edition, p.xx-xx

\begin{tabular}{|l|c|c|}
\hline Job status_retired & $\begin{array}{l}0.36 \\
(0.86)\end{array}$ & 1.43 \\
\hline Job status_student & $\begin{array}{c}-1.78 \\
(1.29)\end{array}$ & 0.17 \\
\hline \% correct classification (Block 1) & \multicolumn{2}{|c|}{88.7} \\
\hline Omnibus Chi-square stat. & $653.59($ sig $=0.00)$ \\
\hline Hosmer \& Lemeshow Test stat. & $2.32($ sig. $=0.97)$ \\
\hline Cox \&Snell R-square & 0.539 \\
\hline Negelkerke R-square & 0.719 \\
\hline
\end{tabular}

Note: Standard errors are in parentheses;

***statistically significant at the $1 \%$ level; $* * 5 \%$ level; * $10 \%$ level.

the base category. The positive value of beta $(\beta)$ for 'Income level more than RM2000 per month', that is 5.86, indicates that an increase in independent variable score as compared to the base category (income level less than RM500 per month) will result in an increased probability of the case recording a score of 1 or 'yes' in the dependent variable (ie. the use of CC as an alternative to RM). The odd ratio $(\operatorname{Exp}(\beta))$ for this variable is 349.02 . This could be interpreted that the odds of a person answering 'yes', that CC can be an alternative to RM, is 349 times higher for someone who earn income more than RM2000 per month as compared to those who earn less than RM500 per month, all other factors being equal. Positive and significant $\beta$ values for dummy variables of 'agricultural product is suitable as $\mathrm{CC}$ ' and 'unused tool is suitable as $\mathrm{CC}$ ' suggest that those who say that agricultural product and unused tools are suitable as $\mathrm{CC}$ for Orang Asli community are more likely to opt for the local currency. Similarly, $\beta$ values for dummy variables ' $\mathrm{CC}$ should be backed by RM' and 'CC should be able to defer transaction' are positive and significant. The results imply that those who state that CC should be backed by RM and able to be kept for future transaction (deferred payment) are more likely to say that $\mathrm{CC}$ can be an alternative of the national currency than those who state that $\mathrm{CC}$ should not be backed by RM and CC should not be able to be kept for future transaction, other things equal. Moreover, coefficient of dummy variable 'Will use CC if it benefits me and family members' is positive and significant implying that the probability of the case recording a score of 1 or 'yes' to the local currency increases as the respondents state that they will use CC if it benefits themselves and their family members. Observing the odd ratios of these variables, they represent the change in odds of being in one of the categories of outcome when the value of each predictor increases by one unit. For dummy variable of 'agricultural product is suitable as CC', the odds of a person answering 'yes' to $\mathrm{CC}$, is 14.19 times higher for someone who reports that agricultural product is suitable for CC than for a person who reports agricultural product is not suitable for $\mathrm{CC}$. The odds of a person answering 'yes' that $\mathrm{CC}$ can be an alternative to RM is 2.92 times higher for someone who says that unused tools is suitable for $\mathrm{CC}$ than for a person who says unused tools is not suitable for $\mathrm{CC}$, all other factors being equal. The odds of a person opts of CC as an alternative currency is 5.69 times higher for someone who reports that $\mathrm{CC}$ should be backed by national currency than who reports that $\mathrm{CC}$ should not be backed by national currency. The odds of opting $\mathrm{CC}$ as an alternative currency is 3.79 times higher for a person who says that $\mathrm{CC}$ should be able to defer transaction than a person who says otherwise and 4.13 times higher for a person who says that he/she will use CC if it benefits him/herself and his/her family members than who says otherwise, other things equal. The negative coefficient of dummy variable of 'prefer to use RM among members of local community' implies that an increase in the independent variable score results in a decreased probability of the case recording a score of 1 or 'yes' in the dependent variable. In other words, the probability that the respondent opts for $\mathrm{CC}$ as an alternative for RM declines when the respondent states that he/she prefer to use RM among community members as compared to those who not prefer to use RM among the members of community. The odd ratio for this variable is 0.72 , a value less than 1 , which means that those who states that he/she prefers to use RM among local community, the odds of him/her reporting that he/she .chooses $\mathrm{CC}$ to replace national currency decrease by a factor of 0.72 , all other factors being equal

In the classification table, with no predictor, the overall percent of correctly classified cases is $51 \%$. When a set of predictor variables is entered, it improves the accuracy of this prediction to $88.7 \%$.

Submit Date: 11.12.2017, Acceptance Date: 25.03.2018, DOI NO: 10.7456/1080SSE

Research Article - This article was checked by Turnitin

Copyright $\odot$ The Turkish Online Journal of Design, Art and Communication 
Since the Omnibus tests of Model coefficients are significant (p-value $<0.05)$, the model with set of variables used as predictors is better than the model with no predictor. The Chi-square value in this test is 653.59 with 31 degree of freedom. The Hosmer \& Lemeshow test also supports the 'goodness of fit' of the model with the Chi-square statistics of 2.32 and significance level of 0.97 . The pseudo R-square statistics (Cox \& Snell R-square and Nagelkerke R-square) show that between $54 \%$ and $72 \%$ of the variability in the dependent variable is explained by the set of predictor variables.

\section{Structural model testing}

A structural model is also estimated based on TAM. The goodness-of-fit statistics of the proposed model showed that the model reasonably fits the current data. Chi-square value of the model $\left(\chi^{2}=\right.$ $2142.504, \mathrm{df}=550, \mathrm{p}=0.000$ ) and other goodness of fit indices (Normed $\chi^{2}=3.895$; RMSEA $=$ $0.052 ; \mathrm{CFI}=0.973$ ) revealed that the model fit the data reasonably well. The structural results of the proposed model are depicted in Fig. 2.

The hypotheses are examined by looking at the significance, signs, and the magnitude of the estimated coefficients (Hair et al. 2006). The path coefficients of the structural model have been measured to assess the statistical significance of the path coefficients. Path coefficients are standardized versions of linear regression weights which can be used in examining the possible causal linkage between statistical variables in the structural equation modeling approach.

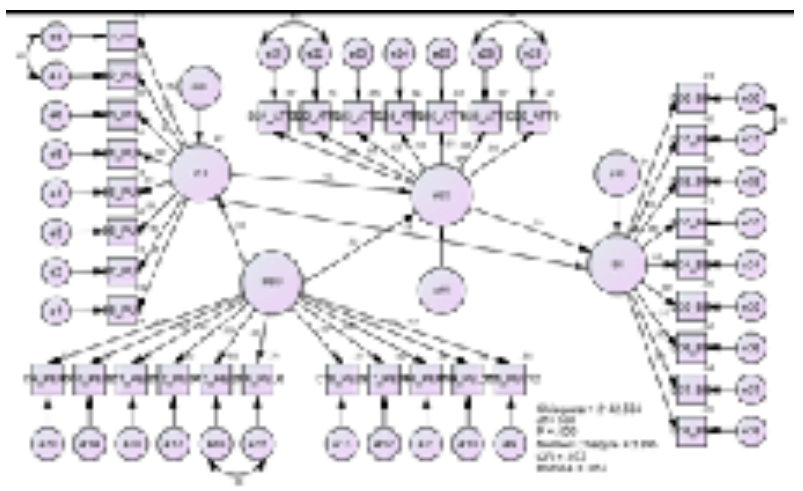

Fig. 2: Structural Model

Table 2: Results of TAM

\begin{tabular}{|l|l|c|c|c|}
\hline \multicolumn{2}{|c|}{ Hypothesized Path } & $\begin{array}{c}\text { Standardized } \\
\text { Coefficient , } \beta 1\end{array}$ & $\begin{array}{c}\text { t- } \\
\text { value }\end{array}$ & $\begin{array}{c}\text { p- } \\
\text { value }\end{array}$ \\
\hline H1 & $\begin{array}{l}\text { Perceived usefulness (PU) } \rightarrow \\
\text { Behaviour Intention (BI) }\end{array}$ & 0.22 & $\begin{array}{c}45.71 \\
*\end{array}$ & 0.000 \\
\hline H2 & $\begin{array}{l}\text { Perceived usefulness (PU) } \rightarrow \\
\text { Attitude toward behaviour (ATT) }\end{array}$ & 0.16 & $4.10^{*}$ & 0.000 \\
\hline H3 & $\begin{array}{l}\text { Perceived Ease of Use (PEOU) } \rightarrow \\
\text { Attitude toward behaviour (ATT) }\end{array}$ & 0.82 & $20.0^{*}$ & 0.000 \\
\hline H4 & $\begin{array}{l}\text { Attitude toward behaviour (ATT) } \rightarrow \\
\text { Behaviour Intention (BI) }\end{array}$ & 0.78 & $6.88^{*}$ & 0.000 \\
\hline H5 & $\begin{array}{l}\text { Perceived Ease of Use (PEOU) } \rightarrow \\
\text { Perceived usefulness (PU) }\end{array}$ & 0.96 & $20.0^{*}$ & 0.000 \\
\hline
\end{tabular}

As shown on Table 2, the result on the relationship between PU and BI is statistically significant $(\beta 1=0.22, \mathrm{t}$-value $=45.71, \mathrm{p}<0.01)$ and supporting the research hypothesis. The result of standardized coefficient shows that if PU goes up by 1 standard deviation, behavioral intention goes up by 0.22 standard deviations. It is perceived that the proposed $\mathrm{CC}$ has a positive effect on the performance of the Orang Asli community economically and/or socially which later might also give positive impact on the behavior of the Orang Asli community toward using the system. The 


\section{The Turkish Online Journal of Design, Art and Communication - TOJDAC ISSN: 2146-5193, September 2018 Special Edition, p.xx-xx}

relationship between PU and ATT is also found to be positive and significant ( $\beta 1=0.16$, t-value $=$ $4.10, \mathrm{p}<0.01$ ), which implies that if PU increases by 1 standard deviation, ATT increases by 0.16 standard deviation. Since PU is referred to job related productivity, performance and effectiveness of the system, it is an important belief that gives insight into how users' attitude towards using the CC system are influenced. Similarly, PEOU and ATT are found to be significantly related positively $(\beta 1=$ $0.82, \mathrm{t}$-value $=20.0, \mathrm{p}<0.01$ ). The believes that using a proposed system would be free from effort and feeling comfortable using will induce the person to use the proposed $\mathrm{CC}$ model which reflects the attitude towards using CC. Our finding are supported by previous studies by Al-Gahtani and King (1999), Lu and Gustafson (1994), Moore and Benbasat (1991) and Venkatesh and Davis (1996). There is also significant relationship between ATT and BI $(\beta 1=0.78$, t-value $=6.88, \mathrm{p}<0.01)$. The attitude of Orang Asli community includes positive thinking and other characteristics that affect their intention to use CC model proposed. Attitudes are an individual's disposition to respond in favor of or against an event. Attitudes could be positive or negative because they are evaluative in nature through indirect measures (Fishbein and Ajzen, 2010). When the respondents have a more positive view about the outcome of involving the proposed CC model, the more favorable their attitude towards the behavior and subsequently, the stronger their intention to take the initiative to use $\mathrm{CC}$ to boost their economic and social performance. Therefore, attitude strongly predicts behavioural intention of the proposed model. Moreover, the result is not surprisingly as many studies have been found out that attitude was an influential factor for behavioral intentions. This outcome is consistent with the findings from Ramayah and Suki (2006), Brown, (1999) and Bentler and Speckarts (1981). Nonetheless, PEOU and PU are found to be related significantly $(\beta 1=0.96, \mathrm{t}$-value $=20.0, \mathrm{p}<0.01)$. Improvement in perceived ease of use may contribute to improved performance (Lu et.al, 2003) and this is proven from the results obtained. The $\mathrm{CC}$ model that acceptable by the community which is easy to be use and free from any risk is believed could contribute better to the objectives of the system to improve the performance of the users. In this case, the convenience of the proposed system is expected to improve the standard of living of the community.

\section{Conclusion}

The present study attempts to propose few CC models to Orang Asli community in Malaysia and assesses the probability that the members of community will opt for the proposed models of the CC. The main barrier to matching the unmet needs with the underutilized resources is a lack of money. Local currency allows localities and regions to create real wealth in their local economy by matching the unmet needs with the underutilized resources. Results from logistic regression implies that the probability to opt for $\mathrm{CC}$ as an alternative currency is high using agricultural products as compared to unused tools provided that $\mathrm{CC}$ should be backed by national currency and it benefits the respondents and their family members. The probability of using $\mathrm{CC}$ is also high among higher income respondents but low for those with big family size and those who prefer to use RM. Using TAM, it is found that perceived usefulness and perceived ease of use have positive effect on attitude to use the proposed CC. Similar results are found between perceived usefulness and behavioral intention to use the proposed $\mathrm{CC}$. Thus, through positive attitude toward using CC, the respondent's perceptions on the usefulness and ease of use positively affect the behavioral intention of using the new system. Even though the proposed $\mathrm{CC}$ model is very alien to the community as they are use to national currency in their daily life activities, surprisingly they are able to accept the new $\mathrm{CC}$ model with positive attitudes, particularly by using agricultural products that they might have them abundant and could be used in the model. The results are useful to the policy makers to probably introduce the CC model to the community which is at the disadvantages, such as the poor and those whose are badly affected from economic recession. The use of CC might be able to boost their economic activities using the unused resources which match to the unmet wants without using the formal form of money.

\section{Acknowledgment}

This study is extracted from of a research project funded by the Fundamental Research Grant Scheme (FRGS) 2015, Ministry of Higher Education, Malaysia. The authors would like to thank the Ministry for generously funding the research. 
The Turkish Online Journal of Design, Art and Communication - TOJDAC ISSN: 2146-5193, September 2018 Special Edition, p.xx-xx

\section{REFERENCES}

Al-Gahtani, S.S. and King, M. (1999). Attitudes, satisfaction and usage: factors contributing to each in the acceptance of information technology. Behaviour and Information Technology, 18(4): 277-297

Bentler, P. M. and Speckart, G. (1981). Attitudes cause behaviour: A structural equation analysis. .Journal of Personality and Social Psychology, 40(2): 226-238

Brown, S. (1999). Public Attitudes Toward The Treatment Of Sex Offenders. Legal and Criminological Psychology, 4: 239-252.

Davis, F. D. (1989), Perceived usefulness, perceived ease of use, and user acceptance of .information technology. MIS Quarterly, 13(3), 319-340

DeMeulenaere, S. (2007). 2006 Annual Report of the Worldwide Database Of Complementary Currency Systems. International Journal of Community Currency Research, Vol. 11. See also URL //http://www.le.ac.uk/ulmc/ijccr

.Douthwaite, R. (1999). The ecology of money. Green Books, Dartington, Totnes

Fishbein, M., and Ajzen, I. (2010). Predicting and changing behavior: The reasoned action . approach. Taylor \& Francis, New York

Hair, J.F, Tatham, R.L., Anderson, R.A. and Black, W. (2006). Multivariate Data Analysis. $6^{\text {th }}$ ed. Prentice -Hall, Upper Saddle River, NJ.

Helleiner, E. (2000). Think globally, transact locally: Green political economy and the local .currency movement. Global Society, 14(1): 35-51

Jabatan Kemajuan Orang Asli (JAKOA)(2016). Pelan Strategik Kemajuan Orang Asli 2011-2015,

Centre for Orang Asli Concerns. See also URL http://www.coac.org.my

.Kent, D. (2005). Healthy money, healthy planet. Craig Potton, Nelson, NZ

Lieter, B., and Hallsmith, G. (2006). Community currency guide. Montpelier, VT:Global

Community Initiatives. See also URL http://www.community-exchange.org/docs/

.community currency guide.pdf

Longhurst, $\bar{N}$. and Seyfang, G. (2011). Harnessing grassroots innovations: Complementary

currencies and sustainability. Paper presented at the International Event on Community and Complementary Currencies, Lyon, February 16-17, 2011. See also URL http:// conferences.ishlyon.cnrs.fr/index.php/cc conf/2011/paper/view/64/31

Lu, H., and H. Gustafson (1994). An Empirical Study of Perceived Usefulness and Perceived Ease of Use on Computerized Support System Use over Time. International Journal of Information .Management ,14(5): 317-329

Lu, J., Yu, C-S., Liu, C. and J. E. Yao, (2003). Technology acceptance model for wireless Internet, ,Internet Research. 13(3): 206-222

Nicholas, C. (2002). Indigenous politics, development and identity in Peninsular Malaysia: The Orang Asli and the contest for resources. Paper presented at Indigenous Rights in the Commonwealth .Project South and South East Asia Regional Expert Meeting. New Delhi, India

Nicholas, C. (2011). Speech at the United Nations (Malaysia). See also URL http://

www.coac.org.my/main.php? section=articles\&article_id $=124$

North, P. (2006). Alternative Currency Movements As A Challenge To Globalisation? A case study .of Manchester's local currency networks. Ashgate, Aldershot

.North, P. (2010). Local money. Green Books, Totnes

Ramayah T. and Suki N.M. (2006). Intention To Use Mobile Pc Among MBA Students:

.Implications For Technology Integration In The Learning Curriculum. UNITAR E-Journal , 2(2)

Schroeder, R., Miyazaki, Y., and Fare, M. (2011). Community currency research: An analysis of the literature. International Journal of Community Currency Research, 15(A): 31-41

Seyfang, G. (2009). The new economics of sustainable consumption. Palgrave Macmillan,

. Basingstoke

Venkatesh, V., and F.D. Davis (1996). A Model of the Antecedents of Perceived Ease of Use .Development and Test. Decision Sciences 27(3): 451-481

Williams, C. C., Aldridge, T., Tooke, J., Lee, R., Leyshon, A. and Thrift, N. (2001) Bridges into .Work: an evaluation of Local Exchange Trading Schemes (LETS). Policy Press, Bristol Yamane, T. (1967). Statistics. An Introductory Analysis, 2nd Ed. Harper and Row, New York 